\title{
TUGAS, PERAN, DAN FUNGSI GURU DALAM PENDIDIKAN
}

\author{
Ahmad Sopian \\ Sekolah Tinggi Ilmu Tarbiyah Raudhatul Ulum, Sakatiga \\ Email: sopain11223344@gmail.com
}

\begin{abstract}
Abstrak
Guru merupakan unsur yang sangat penting dan tidak bisa diabaikan begitu saja dalam proses belajar mengajar, sebab guru dapat menetukan berhasil atau tidaknya sebuah proses belajar mengajar. Oleh karena itu, dalam proses pendidikan dan pengajaran perlu tersedianya guru yang qualified, artinya ialah disamping menguasai materi pelajaran, metode mengajar, juga mengerti tentang dasardasar pendidikan. Dasar-dasar pendidikan amat sangat penting diketahui oleh seorang guru dalam melaksanakan tugasnya yang mulia sebagai pengajar atau pendidik, hal ini merupakan sebagai sarana untuk membangkitkan dan memotivasi siswa dalam proses belajar mereka. Walaupun penguasaan materinya sangat baik, akan tetapi tidak didukung oleh pengetahuan akan faktor-faktor didaktis, maka akan menimbulkan dampak sebuah hambatan dalam penguasaan materi bagi siswa terhadap apa-apa yang disampaikan oleh guru tersebut. Meskipun terhadap pengalaman belajar justru menjadikan guru lebih mudah dalam menyampaikan pelajaran disertai dengan penggunaan metode yang baik dan tepat.
\end{abstract}

Kata Kunci: Tugas, Peran, Fungsi, Guru

\section{Tugas Guru}

Keberadaan guru bagi suatu bangsa amatlah penting, apalagi suatu bangsa yang sedang membangun, terlebih bagi kehidupan bangsa ditengah-tengah pelintasan zaman dengan teknologi yang kian canggih dan segala perubahan serta pergeseran nilai yang cendrung memberi nuansa kehidupan yang menuntut ilmu dan seni dalam kadar dinamik untuk dapat mengadaptasikan diri.

Guru memiliki tugas, baik yang terikat dengan dinas maupun diluar dinas, dalam bentuk pengabdian. Apabila kita kelompokkan ada tiga jenis tugas guru, yakni :(a). Tugas dalam bidang Profesi, (b). Tugas kemanusian, (c). Tugas dalam bidang Kemasyarakatan.

a. Tugas dalam bidang profesi meliputi mendidik, mengajar, dan melatih. Mendidik berarti meneruskan dan mengembangkan nilai - nilai hidup. Mengajar berarti meneruskan dan mengembangkan ilmu pengetahuan dan teknologi, sedangkan melatih berarti mengembangkan keterampilan - keterampilan pada siswa. 
Volume 1 Nomor 1 Edisi Juni 2016

P-ISSN : 2541-3686

b. Tugas guru dalam bidang kemanusian di sekolah harus menjadikan dirinya sebagai orang tua kedua, ia harus mampu menarik simpati sehingga ia menjadi idola para siswanya.

c. Tugas guru dalam bidang kemasyarakatan, masyarakat menempatkan guru pada tempat yang lebih terhormat di lingkungannya karena dari seorang guru diharapkan dapat memperoleh ilmu pengetahuan. Ini berarti guru berkewajiban mencerdaskan bangsa menuju Indonesia seutuhnya yang berdasarkan pancasila. ${ }^{1}$

Dalam Undang - Undang Republik Indonesia No. 20 tahun 2003 Tentang Sistem Pendidikan Nasional pasal 39 ayat 1 dan 2 dinyatakan bahwa :

1) Tenaga pendidikan bertugas melaksanakan administrasi, pengelolaan, pengembangan, pengawasan, dan pelayanan teknis untuk menunjang proses pendidikan pada satuan pendidikan.

2) Pendidik merupakan tenaga profesional yang bertugas melaksanakan proses pembelajaran, menilai hasil pembelajaran, melakukan pembimbingan dan pelatihan, serta penelitian dan pengabdian pada masyrakat, terutama bagi pendidik pada perguruan tinggi. ${ }^{2}$

Menurut Hamdani Bakran ADz-Dzakiey ada beberapa hal mendasari dari tugas dan tanggung jawab seorang guru, khususnya dalam proses pendidikan dan pelatihan pengembangan kesehatan ruhani (ketakwaan), antara lain :

a. Sebelum melakukan proses pelatihan dan pendidikan, seorang guru harus benar benar telah memahami kondisi mental, spiritual, dan moral, atau bakat, minat, maka proses aktivitas pendidikan akan dapat berjalan dengan baik.

b. Membangun dan mengembangkan motivasi anak didiknya secara terus - menerus tanpa ada rasa putus asa. Apabila motovasi ini selalu hidup, maka aktivitas pendidikan atau pelatihan dapat berjalan dengan dengan baik dan lancar.

c. Membimbing dan mengarahkan anak didiknya agar dapat senantisa berkeyakinan, berfikir, beremosi, bersikap dan berprilaku, positif yang berparadigma pada wahyu ketuhanan, sabda, dan keteladanan kenabian.

d. Memberikan pemahaman secara mendalam dan luas tentang materi pelajaran sebagai dasar pemahaman teortis yang objektif, sistematis, metodologis, dan argumentatif.

e. Memberikan keteladanan yang baik dan benar bagaimana cara berfikir, berkeyakinan, beremosi, bersikap, dan berprilaku yang benar, baik dan terpuji baik di hadapan Tuhannya maupun dilingkungan kehidupan sehari - hari.

f. Membimbing dan memberikan keteladanan bagaimana cara melaksanakan ibadah ibadah vertical dengan baik dan benar, sehingga ibadah - ibadah itu akan mengantarkan kepada perubahan diri, pengenalan, dan perjumpaan dengan hakikat diri, pengenalan dan perjumpaan dengan Tuhannya serta menghasilkan kesehatan ruhaninya.

\footnotetext{
${ }^{1}$ Moh. Uzer Usman, Menjadi G uru Profesional,( Bandung : PT Remaja Rosdakarya, Edisi Kedua, 2005) Cet. 17. hal, 7 hal, 28.

${ }^{2}$ Undang-Undang Sisdiknas Th 2003, (Jogjakarta: Media Wacana, 2003) Bab XI Pasal 39 Ayat 1 \& 2,
} 
g. Menjaga, mengontrol, dan melindungi anak didik secara lahiriah maupun batiniah selama proses pendidikan dan pelatihan, agar terhindar dari berbagai macam gangunaan.

h. Menjelaskan secara bijak (hikmah) apa - apa yang ditanyakan oleh anak didiknya tentang persoalan - persoalan yang belum dipahaminya.

i. Menyediakan tempat dan waktu khusus bagi anak didik agar dapat menunjang kesuksesan proses pendidikan sebagaimana diharapkan. ${ }^{3}$

Sesengguhnya tugas guru dalam pedidikan sangatlah penting, seorang guru adalah kunci yang akan membukakan hakikat pengetahuan dan ilmu baik secara teoritis, praktis, maupun empiris.

\section{Peran dan Fungsi Guru.}

Guru memilki satu kesatuan peran dan fungsi yang tak terpisahkan, antara kemampuan mendidik, membimbing, mengajar, dan melatih. Keempat kemampuan tersebut merupakan kemampuan integrativ, yang satu sama lain tak dapat dipisahkan dengan yang lain. ${ }^{4}$ Secara terminologis akademis, pengertian mendidik, membimbing, mengajar, dan melatih dapat dijelaskan dalam table berikut ini.

\section{Tabel 1}

\section{Perbedaan antara Mendidik, Membimbing, Mengajar, Dan Melatih.}

\begin{tabular}{|c|c|c|c|c|c|}
\hline No & Aspek & Mendidik & Membimbing & Mengajar & Melatih \\
\hline 1. & Isi & $\begin{array}{l}\text { Moral dan } \\
\text { kepribadian }\end{array}$ & Norma dan tata tertib & $\begin{array}{l}\text { Bahan ajar berupa ilmu } \\
\text { pengetahuan dan } \\
\text { teknologi }\end{array}$ & $\begin{array}{l}\text { Keterampilan atau } \\
\text { kecakapan hidup } \\
\text { (life skills) }\end{array}$ \\
\hline 2. & Proses & $\begin{array}{l}\text { Memberikan } \\
\text { motivasi untuk } \\
\text { belajar dan } \\
\text { mengikuti } \\
\text { ketentuan atau tata } \\
\text { tertib yang telah } \\
\text { menjadi } \\
\text { kesepakatan } \\
\text { bersama }\end{array}$ & $\begin{array}{l}\text { Menyampaikan atau } \\
\text { mentransfer bahan ajar } \\
\text { yang berupa ilmu } \\
\text { pengetahuan, teknologi } \\
\text { dan seni dengan } \\
\text { menggunakan strategi } \\
\text { dan metode mengajar } \\
\text { yang sesuai dengan } \\
\text { perbedaan siswa. }\end{array}$ & $\begin{array}{l}\text { Memberikan contoh } \\
\text { kepada siswa atau } \\
\text { mempraktikkan } \\
\text { keterampilan tertentu } \\
\text { atau menerapkan } \\
\text { konsep yang telah } \\
\text { diberikan kepada siswa } \\
\text { menjadi kecakapan } \\
\text { yang dapat digunakan } \\
\text { dalam kehidupan } \\
\text { sehari-hari }\end{array}$ & $\begin{array}{l}\text { Menjadi contoh } \\
\text { dan teladan dalam } \\
\text { hal moral dan } \\
\text { kepribadian. }\end{array}$ \\
\hline 3. & $\begin{array}{l}\text { Strategi } \\
\text { dan } \\
\text { metode }\end{array}$ & $\begin{array}{l}\text { Keteladanan, } \\
\text { pembiasaan }\end{array}$ & Motivasai dan pembinaan & Ekspositori dan enkuiri & $\begin{array}{l}\text { Praktek kerja, } \\
\text { simulasi, dan } \\
\text { magang. }{ }^{5}\end{array}$ \\
\hline
\end{tabular}

${ }^{3}$ Hamdan Bakran Adz-Dzakiey, Prophetic Intelelligence; Kecerdasan Kenabian " Menumbuhkan Potensi Hakekat Insani Melalui Pengembangan Kesehatan Ruhani ” (Jogjakarta :Islamika, 2004). hal,577-578

${ }^{4}$ Suparlan, Guru Sebagai Profesi, ( Yogyakarta: Hikayat Publishing, 2006), hal 29.

${ }^{5}$ Suparlan, Menjadi Guru Efektif, ( Yogyakarta: Hikayat Publishing, 2005), hal 26-27. 
P-ISSN : 2541-3686

Secara komprehensif sebenarnya guru harus memiliki keempat kemampuan tersebut secara utuh. Meskipun kemampuan mendidik harus lebih dominan dibandingkan dengan kemampuan yang lainnya.

Dari sisi lain, guru sering dicitrakan memiliki peran ganda yang dikenal dengan EMASLIMDEF ( educator, manager, administrator, supervisor, leader, innovator, dinamisator, evaluator, dan fasilitator). EMASLIM lebih merupakan peran kepala sekolah. Akan tetapi, dalam skala mikro di kelas, peran itu juga harus dimiliki oleh para guru.

Educator merupakan peran yang utama dan terutama, khususnya untuk peserta didik pada jenjang pendidikan dasar (SD dan SMP). Peran ini lebih tampak sebagai teladan bagi peserta didik, sebagai role model, memberikan contoh dalam hal sikap dan perilaku, dan membentuk kepribadian peserta didik.

Sebagai manager, pendidik memiliki peran untuk menegakkan ketentuan dan tata tertib yang telah disepakati bersama di sekolah, memberikan arahan atau rambu-rambu ketentuan agar tata tertib di sekolah dapat dilaksanakan dengan sebaik-baiknya oleh warga sekolah.

Sebagai administrator, guru memiliki peran untuk melaksanakan administrasi sekolah, seperti mengisi buku presensi siswa, buku daftar nilai, buku rapor, administrasi kurikulum, administrasi penilaian dan sebagainya. Bahkan secara administrative para guru juga sebaiknya memiliki rencana mengajar, program smester dan program tahunan, dan yang paling penting adalah menyampaikan rapor atau laporan pendidikan kepada orang tua siswa dan masyarakat.

Peran guru sebagai supervisor terkait dengan pemberian bimbingan dan pengawasan kepada peserta didik, memahami permasalahan yang dihadapi peserta didik, menemukan permasalahan yang terkait dengan proses pembelajaran, dan akhirnya memberikan jalan keluar pemecahan masalahnya.

Peran sebagai leader bagi guru lebih tepat dibandingkan dengan peran sebagai manager. Karena manager bersifat kaku dengan ketentuan yang ada. Dari aspek penegakan disiplin misalnya, guru lebih menekankan disiplin mati. Sementara itu, sebagai leader guru lebih memberikan kebebasan secara bertanggung jawab kepada peserta didik. Dengan demikian, disiplin yang telah ditegakkan oleh guru dari peran sebagai leader ini adalah disiplin hidup.

Dalam melaksanakan peran sebagai innovator, seorang guru harus memiliki kemauan belajar yang cukup tinggi untuk menambah pengetahuan dan keterampilannya sebagai guru. Tanpa adanya semangat belajar yang tinggi, mustahil bagi guru dapat menghasilkan inovasi-inovasi yang bermanfaat untuk meningkatkan mutu pembelajaran di sekolah.

Adapun peran sebagai motivator terkait dengan peran sebagai educator dan supervisor. Untuk meningkatkan semangat dan gairah belajar yang tinggi, siswa perlu memiliki motivasi yang tinggi, baik motivasi dari dalam dirinya sendiri (intrisik) maupun dari luar (ekstrinsik), yang utamanya berasal dari gurunya sendiri. ${ }^{6}$

\footnotetext{
${ }^{6}$ Ibid, hal. 29
} 
Dalam buku bertajuk Dinamika Sekolah dan Bilik Darjah, Kamaruddin Haji Husin (1993:8), memaparkan peran guru dalam berbagai aspek. Yaitu sebagai (1). Pendidik , (2) Pengajar, (3) Fasilitator, (4) Pembimbing, (5) Pelayan, (6) Perancang, ( 7) Pengelola, (8) Inovator, dan (9) Penilai. ${ }^{7}$

Menurut kajian Pullias dan Young (1998), Manan (1990), serta Yelon And Weinstein (1997), dapat diidentifikasikan sedikitnya ada 19 peran guru, yakni guru sebagai pendidik, pengajar, pembimbing , pelatih, penasehat, pembaharu (innovator), model dan keteladanan, pribadi, peneliti, pendorong kreativitas, pembangkit pandangan, pekerja rutin, pemindah kemah, pembawa ceritera, actor, emancipator, evaluator, pengawet dan kulminator. 8

Semua orang yakin bahwa guru memiliki andil yang sangat besar terhadap keberhasilan pembelajaran di sekolah. Guru sangat berperan dalam membantu perkembangan peserta didik untuk mencapai tujuan hidup secara optimal. Keyakinan ini muncul karena manusia adalah makhluk lemah, yang dalam perkembangan senantiasa membutuhkan orang lain, sejak lahir, bahkan pada saat meninggal.

Pembelajaran pada hakikatnya adalah proses interaksi antara peserta didik dengan lingkungan, sehingga terjadi perubahan perilaku ke arah yang lebih baik. Dalam interaksi tersebut banyak sekali factor yang mempengaruhi baik internal maupun eksternal.

Dalam pembelajaran, tugas guru yang paling utama adalah mengkondisikan lingkungan agar menunjang terjadinya perubahan perilaku bagi peserta didik. Umumnya pelaksanaan pembelajaraan mencangkup tiga hal yaitu :

\section{a. Pre Tes ( Tes Awal)}

Pada umumnya pelaksanaan proses pembelajaraan dimulai dengan pre tes. Pre tes ini mempunyai banyak kegunaan dalam menjajaki proses pembelajaran yang akan dilaksanakan. Oleh karena itu pre tes memegang peranan yang cukup penting dalam proses pembelajaran.

\section{b. Proses}

Proses pembelajaran perlu dilakukan dengan tenang dan menyenangkan. Hal tersebut tentu saja menurut aktifitas dan kreatifitas guru dalam menciptakan lingkungan yang kondusif. Proses pembelajaran dikatakan efektif apabila seluruh peserta didik terlibat secara aktif, baik mental, fisik, maupun sosialnya.

Kualitas pembelajaran dapat dilihat dari segi proses dan dari segi hasil. Dari segi proses, pembelajaran dapat dikatakan berhasil dan berkualitas apabila seluruhnya atau setidak - tidaknya sebagian besar (75\%) peserta didik terlibat secara aktif, baik fisik, mental maupun social dalam pembelajaran, disamping menunjukkan kegairahan belajar yang tinggi, semangat belajar yang besar dan rasa percaya pada diri sendiri. Sedangkan dari segi hasil, proses pembelajaran dikatakan berhasil apabila terjadi perubahan

\footnotetext{
${ }^{7}$ Suparlan, Guru Sebagai Profesi, ( Yogyakarta: Hikayat Publishing, 2006), hal 37.

${ }^{8}$ E. Mulyasa, Menjadi Guru Professional, Menciptakan Pembelajaran Kreatif dan Menyenangkan (Bandung : Remaja Rosdakarya, 2005). Hal, 37
} 
P-ISSN : 2541-3686

perilakunya yang positif pada diri peserta didik seluruhnya atau setidak - tidaknya sebagaian besar (75\%). Lebih lanjut proses pembelajaran dikatakan berhasil dan berkualitas apabial masukan merata, menghasilkan output yang banyak dan bermutu tinggi, serta sesuai dengan kebutuhan, perkembangan masyarakat dan pembangunan.

\section{c. Post Tes}

Pada umumnya pelaksanaan pembelajaran diakhiri dengan post tes. Sama halnya dengan pre tes, post tes juga memiliki banyak kegunaan, terutama dalam melihat proses pembelajaran. Fungsi post tes antara lain dapat dikemukakan sebagai berikut :

1. Untuk mengetahui tingkat penguasaan peserta didik terhadap kompetensi yang telah ditentukan, baik secara individu maupun kelompok.

2. Untuk mengetahui kompetensi dan tujuan - tujuan yang dapat dikuasai oleh peserta didik, serta kompetensi dan tujuan - tujuan yang belum dikuasainya.

3. Untuk mengetahui peserta didik - peserta didik yang perlu remedial, dan peserta didik yang mengikuti pengayaan, serta untuk mengetahui tingkat kesulitan dalam mengerjakan modul (kesulitan belajar).

4. Sebagai bahan acuan untuk melakukan perubahan terhadap komponen modul dan proses pembelajaran yang telah dilakuakn baik terhadap perencanaan, pelaksanaan maupun evaluasi. ${ }^{9}$

Guru juga harus berpacu dalam pembelajaran, dengan memberikan kemudahan belajar bagi seluruh peserta didik, agar dapat mengembangkan potensinya secara optimal. Dalam hal ini, guru harus kreatif, professional, dan menyenangkan, dengan memposisikan diri sebagai berikut :

a. Orang tua yang penuh kasih sayang pada peserta didiknya.

b. Teman, tempat mengadu, dan mengutarakan perasaan bagi peserta didik.

c. Fasilitator yang selalu siap memberikan kemudahan, dan melayani peserta didik sesuai minat, kemampuan, dan bakatnya.

d. Memberikan sumbangan pemikiran pada orang tua untuk dapat mengetahui permasalahan yang dihadapi anak dan memberikan saran pemecahannya.

e. Memupuk rasa percaya diri, berani dan bertanggung jawab.

f. Membiasakan peserta didik untuk selalu berhubungan (silaturahmi) dengan orang lain secara wajar.

g. Mengembangkan proses sosialisasi yang wajar antar peserta didik, orang lain, dan lingkungannya.

h. Mengembangkan kreativitas.

i. Menjadi pembantu ketika diperlukan. ${ }^{10}$

\footnotetext{
${ }^{9}$ E. Mulyasa, Kurikulum Berbasis Kompetensi : Konsep, Karakteristik dan Implementasi, (Bandung: Remaja Rosdakarya, 2004), hal, 100-103

${ }^{10}$ E. Mulyasa, Menjadi Guru Professional, Menciptakan Pembelajaran Kreatif dan Menyenangkan (Bandung : Remaja Rosdakarya, 2005). Hal, 36
} 
Untuk mengembangkan tuntutan diatas, guru harus mampu memaknai pembelajaran, serta menjadikan pembelajaran sebagai ajang pembentukan kompetensi dan perbaikan kualitas pribadi peserta didik.

\section{Profesi Guru}

Profesi pada hakekatnya adalah suatu pernyataan atau suatu janji terbuka yang menyatakan bahwa seseorang itu mengabdikan dirinya pada suatu jabatan atau pelayanan karena orang tersebut merasa terpanggil untuk menjabat pekerjaan itu. Mengenai istilah profesi, Everett Hughes yang dialih bahasakan oleh Piet A. Sahertian menjelaskan bahwa istilah profesi merupakan simbol dari suatu pekerjaan dan selanjutnya menjadi pekerjaan itu sendiri. ${ }^{13}$

Menurut Chandler yang dialih bahasakan oleh Piet A. Sahertian menegaskan bahwa profesi mengajar adalah suatu jabatan yang mempunyai kekhususan. Kekhususan itu memerlukan kelengkapan mengajar dan atau keterampilan yang menggambarkan bahwa seseorang melakukan tugas mengajar yaitu membimbing manusia dan mempunyai ciri-cirinya adalah sebagai berikut : ${ }^{14}$

Suatu profesi menunjukkan bahwa orang itu lebih mementingkan layanan kemanusiaan dari pada kepentingan pribadi.

a. Masyarakat mengakui bahwa profesi itu punya status yang tinggi.

b. Praktek profesi itu didasarkan pada suatu penguasaan pengetahuan yang khusus.

c. Profesi itu selalu di tantang agar orangnya memiliki keaktivan intelektual.

d. Hak untuk memiliki standar kualifikasi profesional ditetapkan dan dijamin oleh kelompok organisasi profesi.

Seorang guru dikatakan profesional bila guru memiliki kualitas mengajar yang tinggi. Padahal profesional mengandung makna yang lebih luas dari hanya berkualitas tinggi dalam hal teknis. Guru bukan hanya pengajar, tetapi juga pendidik. Melalui pengajaran guru membentuk konsep berpikir, sikap jiwa dan menyentuh afeksi yang terdalam dari inti kemanusiaan subjek didik.

Guru berfungsi sebagai pemberi inspirasi. Guru membuat si terdidik dapat berbuat. Guru menolong agar subjek didik dapat menolong dirinya sendiri. Guru menumbuhkan prakarsa, motivasi agar subjek didik mengatualisasikan dirinya sendiri. Jadi guru yang ahli mampu menciptakan situasi belajar yang mengandung makna relasi interpersonal. Relasi interpersonal harus diciptakan sehingga subjek didik merasa "diorangkan", subjek didik mempunyai jati dirinya.

Perlu diketahui bahwa terdapat sedikit perbedaan mengenai pengertian dalam menjalankan profesi sebagai guru. Dalam penelitian yang dilakukan penulis adalah profesi tentang guru agama Islam. Pengertian guru sebagaimana telah disinggung diatas menurut Zakiyah Darajat, adalah pendidik profesional karena secara implisit ia telah merelakan dirinya menerima dan memikul sebagian tanggung jawab pendidikan yang terpikul di pundak para orang tua. Dengan demikian dapat disimpulkan bahwa guru secara umum dapat memberikan sebuah tanggung jawab kepada anak didiknya melalui ilmu secara umum. Kemudian guru agama Islam lebih khusus kepada ilmu secara khusus, yaitu memberikan pengajaran secara formil kepada anak didiknya untuk mempelajari ilmu agama Islam dalam jangka waktu tertentu dengan kurikulum dan metode yang telah disiapkan.

13 Ibid, hlm. 26.
14 Ibid, hlm 27. 
Volume 1 Nomor 1 Edisi Juni 2016

P-ISSN : 2541-3686

Hakikat manusia adalah sebagai pribadi yang utuh, yang mampu menentukan diri sendiri atas tanggung jawab sendiri. Guru yang ahli harus dapat menyentuh inti kemanusiaan subjek didik melalui pelajaran yang diberikan. Ini berarti bahwa cara mengajar guru harus diubah dengan cara yang bersifat dialogis dalam arti yang ekstensial. Jadi jabatan guru di samping sebagai pengajar, pembimbing dan pelatih pula dipertegas sebagai pendidik.

Guru dibentuk bukan hanya untuk memiliki seperangkat keterampilan teknis saja, tetapi juga memiliki kiat mendidik serta sikap yang profesional. Dengan demikian praktek pengalaman calon guru harus lebih lama sekurang-kurangnya satu tahun agar mereka memperoleh peningkatan dan kelengkapan profesional yang mantap sebelum terjun dalam dunia mengajar.

Guru yang profesional di samping ahli dalam bidang mengajar dan mendidik, ia juga memiliki otonomi dan tanggung jawab. Yang dimaksud dengan otonomi adalah suatu sikap yang profesional yang disebut mandiri. Ia telah memiliki otonomi atau kemandirian yang dalam mengemukakan apa yang harus dikatakan berdasarkan keahliannya. Pada awalnya ia belum punya kebebasan atau otonomi. Ia masih belajar sebagai magang. Melalui proses belajar dan perkembangan profesi maka pada suatu saat ia akan memiliki sikap mandiri.

Pengertian bertanggung jawab menurut teori ilmu mendidik mengandung arti bahwa seseorang mampu memberi pertanggung jawaban dan kesediaan untuk diminta pertanggung jawaban. Tanggung jawab yang mengandung makna multidimensional ini berarti bertanggung jawab terhadap diri sendiri, terhadap siswa, terhadap orang tua, lingkungan sekitarnya, masyarakat, bangsa dan negara, sesama manusia dan akhirnya terhadap Tuhan Yang Maha Pencipta. ${ }^{15}$

Guru sebagai sosial worker (pekerja sosial) sangat dibutuhkan oleh masyarakat. Namun kebutuhan masyarakat akan guru belum seimbang dengan sikap sosial masyarakat terhadap profesi guru. Rendahnya pengakuan masyarakat terhadap guru menurut Nana Sudjana disebabkan oleh beberapa faktor yaitu :

a. Adanya pandangan sebagian masyarakat bahwa siapa pun dapat menjadi guru, asalkan ia berpengetahuan, walaupun tidak mengerti didaktikmetodik.

b. Kekurangan tenaga guru di daerah terpencil memberikan peluang untuk mengangkat seseorang yang tidak mempunyai kewenangan profesional untuk menjadi guru.

c. Banyak tenaga guru sendiri yang belum menghargai profesinya sendiri, apabila berusaha mengembangkan profesi tersebut. Perasaan rendah diri karena menjadi guru masih menggelayut di hati mereka sehingga mereka melakukan penyalahgunaan profesi untuk kepuasaan dan kepentingan pribadi yang hanya akan menambah pudar wibawa guru dimata masyarakat. ${ }^{16}$

Salah satu hal menarik pada ajaran Islam adalah penghargaan yang tinggi terhadap guru. Begitu tingginya penghargaan ini sehingga menempatkan kedudukan guru setingkat di bawah kedudukan Nabi dan Rosul. Mengapa demikian, karena guru adalah bapak rohani (spiritual father) bagi anak didik yang memberi santapan jiwa dengan ilmu pengetahuan.

Penghargaan Islam terhadap orang yang berilmu tergambar dalam hadist seperti dikutip oleh Ahmad Tafsir, yaitu:

a. Tinta ulama lebih berharga dari pada darah para syuhada.

b. Orang yang berpengetahuan melebihi orang yang senang beribadah, orang yang berpuasa, melebihi kebaikan orang yang berperang di jalan Allah.

\footnotetext{
15 Amier Daien Indrakusuma, Pengantar Ilmu Pendidikan, (Surabaya : Usaha Nasional, 1999), hlm. 34
}

6 Hasbullah, Dasar-dasar Ilmu Pendidikan, (Jakarta : Rajawali, 1999), hlm 192. 


\section{Tugas, Peran dan Fungsi Guru dalam Pendidikan}

\section{Ahmad Sopian}

c. Apabila meninggal seorang alim maka terjadilah kekosongan dalam Islam yang tidak dapat diisi kecuali oleh orang yang alim pula. ${ }^{17}$

Guru merupakan faktor yang sangat dominan dan paling penting dalam pendidikan formal pada umumnya karena bagi siswa guru sering dijadikan tokoh teladan bahkan menjadi tokoh identifikasi diri. Oleh sebab itu guru seyogyanya memiliki perilaku dan kemampuan yang memadai untuk mengembangkan siswanya secara utuh. Untuk melaksanakan tugasnya secara baik sesuai dengan profesi yang dimilikinya guru perlu menguasai berbagai hal sebagai kompetensi yang dimilikinya.

Guru harus memahami dan menghayati para siswa yang dibinanya karena wujud siswa pada setiap saat tidak akan sama. Sebab perkembangan ilmu pengetahuan dan teknologi yang memberikan dampak serta nilai-nilai budaya masyarakat Indonesia sangat mempengaruhi gambaran para lulusan suatu sekolah yang diharapkan. Oleh sebab itu gambaran perilaku guru yang diharapkan sangat mempengaruhi dan dipengaruhi oleh keadaan itu sehingga dalam melaksanakan proses belajar mengajar, guru diharapkan mampu mengantisipasi perkembangan keadaaan dan tuntutan masyarakat pada masa yang akan datang.

\section{Simpulan}

Guru merupakan figur sentral dalam penyelenggaraan pendidikan, karena guru adalah sosok yang sangat diperlukan untuk memacu keberhasilan peserta didiknya. Betapapun baiknya kurikulum yang dirancang, namun pada akhirnya keberhasilan para siswa sangat tergantung pada pertanggung jawaban guru dalam melaksanakan tugasnya. Perkembangan ilmu pengetahuan dalam kehidupan masyarakat penuh dengan tuntutan dari berbagai sektor sangat berpengaruh pada kehidupan sekolah. Untuk melaksanakan profesinya guru sangat memerlukan aneka ragam pengetahuan dan keterampilan guru yang memadai sesuai dengan tuntutan zaman.

Dalam kegiatan belajar mengajar, guru merupakan pemegang peran yang sangat penting, kepada gurulah tugas dan tanggung jawab, merencanakan dan melaksanakan proses kegiatan belajar mengajar. Pengelolaan kelas merupakan wujud kreatifitas guru untuk mengadakan dan memelihara kondisi belajar yang optimal dan mengembalikannya bila terjadi gangguan dalam proses belajar mengajar. Dalam menjalankan tugas, guru harus memiliki seperangakat kemampuan baik dalam bidang yang akan disampaikan, maupun kemampuan untuk menyampaikan bahan itu agar mudah diterima oleh peserta didik. Adapun kemampuan yang harus dimiliki kaitannya dengan membina anak didik meliputi kemampuan mengawasi, membina, dan mengembangkan kemampuan siswa baik personil, profesional maupun sosial.

\footnotetext{
17 Ibid, hlm 193.
} 
RAUDHAH Proud To Be Professionals Jurnal Tarbiyah)damiyah

Volume 1 Nomor 1 Edisi Juni 2016

P-ISSN : 2541-3686

\section{DAFTAR PUSTAKA}

Adz-Dzakiey, Hamdan Bakran, Prophetic Intelelligence; Kecerdasan Kenabian " Menumbuhkan Potensi Hakekat Insani Melalui Pengembangan Kesehatan Ruhani" (Jogjakarta :Islamika, 2004).

Hasbullah, Dasar-dasar Ilmu Pendidikan, (Jakarta : Rajawali, 1999).

Indrakusuma, Amier Daien, Pengantar Ilmu Pendidikan, (Surabaya : Usaha Nasional, 1999).

Mulyasa, E., Kurikulum Berbasis Kompetensi : Konsep, Karakteristik dan Implementasi, (Bandung: Remaja Rosdakarya, 2004).

Mulyasa, E., Menjadi Guru Professional, Menciptakan Pembelajaran Kreatif dan Menyenangkan (Bandung : Remaja Rosdakarya, 2005).

Suparlan, Guru Sebagai Profesi, ( Yogyakarta: Hikayat Publishing, 2006).

Suparlan, Menjadi Guru Efektif, ( Yogyakarta: Hikayat Publishing, 2005).

Undang-Undang Sisdiknas Th 2003, (Jogjakarta: Media Wacana, 2003) Bab XI Pasal 39 Ayat $1 \& 2$.

Usman, Moh. Uzer, Menjadi G uru Profesional,( Bandung : PT Remaja Rosdakarya, Edisi Kedua, 2005). 